\title{
Congress Visions of Dobrogea and Balcic in Romanian Paintings
}

\author{
Dr. rer. nat. Carmen Sabau CSabau@ comcast.net, \\ and Dr. Isabelle Sabau cyberedu22@ netscape.net
}

\begin{abstract}
The area of Dobrogea with its tremendous biodiversity, beach resorts and fascinating vistas has inspired numerous artists for centuries. This presentation will discuss a number of visionary and artistic interpretations of this alluring landscape and its importance in the development of modern Romanian art.
\end{abstract}

\section{Introduction}

The Dobrogea region in Southeastern Romania, located between the Danube River and the Black Sea, is home to the UNESCO wildlife "Reservation of the Biosphere" of the Danube Delta and numerous historical ancient settlements going back to Neolithic times of which the famous "Thinker and his Wife" dates from the Hamagia period in the $6^{\text {th }}$ Millennium BCE.

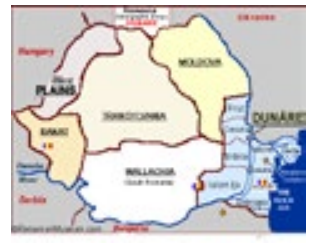

Figure 1. Map of Romania

The Mediterranean and Black sea basin (Figure 1) with its inviting beaches, therapeutic mud baths and ample sunshine has attracted numerous artists throughout the centuries and even more abundantly in the modern period from the $18^{\text {th }}-20^{\text {th }}$ centuries. During the rapid development of the modern world, momentous discoveries, inventions and dramatic changes in all domains of human activity from the social, political and technological realms to the artistic, cultural and philosophical areas, led to fundamental changes in the web of knowledge. As the Impressionist artists had discovered the Cote d'Azur and the minute variations of colors and light, and, as landscape painting itself gained popularity providing an escape from the bustle, noise, pollution and crowds of the modern city, seascapes and beachscapes beckoned the painters of the times with rich sources of inspiration facilitated by the introduction of oil paints in portable tubes. In Romania, while the prominent artists had traveled, studied and painted in France, the Romanian seaside of the abundant region of Dobrogea provided a similar source for inspiration as the French and Italian Rivieras. From the well-known Grigorescu, Tonitza, Luchian, Petrascu, to more contemporary artists such as David Croitor and George Stefanescu, the seaside, Dobrogea and the area of Balcic in present day Bulgaria, have inspired fascinating works of art to be discussed further in this presentation.

\section{Romanian Marinescapes of Dobrogea}

Nicolae Grigorescu (1838-1907), considered the greatest Romanian painter, was instrumental in the evolution of modern Romanian art and the artistic taste of the Romanian public. He was the foremost artist who expressed better than any other artist the nature and soul of Romania and its people as Nicolae Iorga commented [1], the stunning beauty of the Romanian land, the positive and poetic rural life of the peasants, succeeding to create his own unique style. While he studied and acknowledged the importance of the modern developments of Impressionism, the Barbizon School and various artistic techniques, he never became affiliated with any of the contemporary artistic movements, developing instead his own distinctive artistic sensibilities, which enabled him to represent with sensitivity and honesty the landscapes and portraits of peasants, presenting an optimistic aspect of rural life. His works, often idyllic and lyrical, display a vast array of techniques employed to evoke specific feelings in 
the viewer while concentrating on the atmosphere of the subject through a synthesis of ideas.

Diagonal streets, undulating houses and bright colors sparkling in the intense sun punctuated by broad, flat areas of color mark the work of Nicolae Tonitza (1886-1940). (Figure 2)



Figure 2. Nicolae Tonitza Houses Balcic

His rapid sketches of Turk and Tatar children reveal a deep sensitivity to the personality of the sitter, while the seascapes emphasize the vastness of the sea merging into the azure sky glimpsed through the arabesque shapes of the trees. He used to teach his students "The art of the great Colorists doesn't consist of the variety of colors he spreads on the canvas, but in the chromatic musicality that he knows to establish with the help of a minimum of colored substances" [2].

Stefan Luchian (1868-1916) approached the shore with more somber colors rendering the lyrical coloring in subtle nuances while summarily indicating its features. (Figure 3)

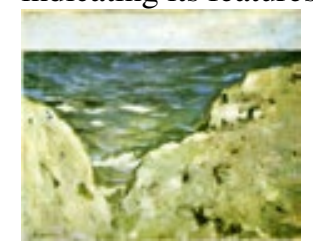

Figure 3. Stefan Luchian Black Sea at Tuzla

Luchian was a master in representing nature, especially Romanian landscapes and a staunch interpreter of the Romanian soul, with its tenderness, melancholy and confidence in the beauty of life [3]. In his landscapes, curved, calm lines dominate undisturbed by sharp angularities, emphasizing tall and slender trees, adorned by rich foliage, catching the sun sometimes with the bright sparkle of enamel and other times discreetly glimmering. He presents restricted views, showing the richness of a small number of trees, a steeple, a backyard, a well or a path in a graveyard, but his harmony of colours and the play of sun rays, brighten up the whole painting without stark contrasts, just shadows of different nuances [4].
Gheorghe Petrascu (1872-1949) highlighted the figures casually strolling on the shore contrasting their indistinct and sketchy features with the vibrant colours of the sea and the vastness of sand focusing the attention of the viewer to the infinite horizon somewhere in the center of the work. His works are characterized by a thick impasto of color applied with a palette knife often using a number of colors simultaneously [5]. His oeuvre shows a great preoccupation with color and light, as he mentioned in an interview in 1931, when asked how he creates such unique light in his works, smiling, he answered: "for more than 30 years, I have been asking myself that, too!'[6]. For Petrascu black is not shadow and white is not light, but they have the same role as every other single color [7].

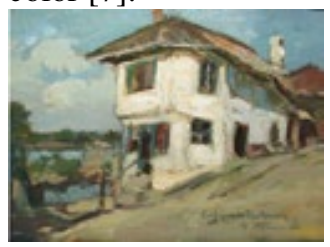

Figure 4. Gheorghe Petrascu Café in Turtucaia

"The Café in Turtucaia" (Figure 4) is typical for that town and occupies the center of the painting, on a downhill street. The white walls offer luminosity and a spotlight amidst the abundance of green hues that dominate the work. Spots of blue appear in the pond on the left side of the house as darker nuances fill the upper right corner. Between 1905 - 1932, Petrascu painted several windmills from Ialomita, Mangalia, Branesti, Balcic, and from Bretagne, as a romantic subject, repeated with different chromatic palettes [8]. In "Looking at the sea at Mangalia", the artist's wife and daughter break the saturated dominance of ultra-marine and the emerald-green. The contrast between the blue of the sea, the yellow of the sand and the red of the dress or between the sky-blue and sea blue and the beach yellow-green are striking and the shadows cast by the figures are apparent. Petrascu started painting marines, already as a student, discontinuing around 1940, because of health problems. Many of his marines are tranquil, serene, sometimes sad, sometimes brilliant, stressing the movement of light and often including his wife, Lucretia Petrascu, their daughter, Mariana, or Lila Marinescu, his wife's sister. In the year, 
1930 Pertrascu painted numerous marines at Techirghiol. The foamy waves and the movement of the dresses exposed to the wind are concentrated in the centre of the composition dominated by grey, ultra-marine and emerald-green accentuated by the usual violet-red of the hats [9]. His chromatic harmonies intensified by the use of black, present a distinctive expression of a constructive vision of the beauty and nobility of matter clothed in light and shadow.

George Stefanescu (1914-2007) was born at Plainesti/Dumbraveni, a small village lying somewhere between Focsani and Ramnicul Sarat [10]. He studied at the Academy of Fine Arts in Bucharest with Nicolae Darascu, whom he accompanied to Balcic, the painters' paradise. (Figure 5)

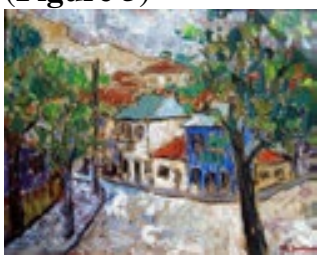

Figure 5. George Stefanescu Balcic street

Later he was a student of Lucian Grigorescu and during the period of 1958-1975 he worked as a set and costume designer for the Municipal Theater. Although better known for numerous costumes and set designs for the Theater, Stefanescu continued to paint and exhibit drawings and watercolors of the Romanian and Bulgarian seasides. In 1974 George Stefanescu retired from the Theater in order to devote himself exclusively to painting and in 1989 he moved to Germany, where he continued his artistic career punctuated by various personal and joint exhibits, culminating with a solo exhibit celebrating the artist's 90's birthday in 2004, organized by the city of Lüdinghausen and the Kunstverein KAKTus entitled "George Stefanescu Licht und Farbe" [11]. Petru Comarnescu described the work of the artist: "The images of George Stefanescu appeal through their warmth of feelings, their bright harmonies and balanced tonalities..."[12].

Lucian Grigorescu (1894-1965), an original Romanian post-Impressionist, fused the perceptual vision of the impressionists with the structural analysis of the post-impressionists and unique Romanian motifs, creating a balance between tradition and modernity, infused with a personal sensibility and delight in nature and rendered through a vigorous construction of form bathed in colour and light. (Figure 6)



Figure 6. Lucian Grigorescu Balcic

\section{Queen Marie and Balcic}

Queen Marie (1875-1938), born Princess Marie Alexandra Victoria of Edinburgh, a granddaughter of Queen Victoria was married, in 1893 to Prince Ferdinand of HohenzollernSigmaringen, who ascended the Romanian throne in 1914, after the death of his uncle King Carol I of Romania. Queen Marie was known as a great beauty, romantically inclined and idealistic, admired throughout the courts of Europe, who dedicated herself with strong resolve and courage to her adoptive country [13]. During WWI she devoted herself to charitable work serving tirelessly as a nurse, setting up her own hospital on the grounds of the Royal Palace, providing meals, blankets and comforts to the wounded and fearlessly touring typhoid stricken villages and foxholes on the front [14]. After WWI, she represented Romania at the Paris Peace Conference at Versailles, helping to smooth conflicts and bring favorable outcomes to Romania, with the promise of giving Romania back her lost territories and not partitioning the country [15].

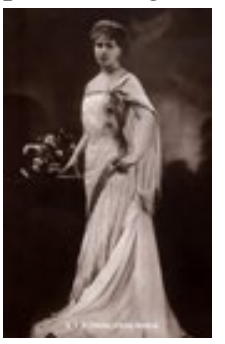

Figure 7. Queen Marie

In her Memoirs Queen Marie (Figure 7) described the Coronation Day and her love for Romania as the crowds cheered:" "Regina Maria!" And we faced each other then, my people and I. And that was my hour - mine - an hour it is not given to many to live; for at that moment it was not only an idea, not 
only a tradition or a symbol they were acclaiming, but a woman - a woman they loved. And at that hour I knew that I had won, that the stranger, the girl who had come from over the seas, was a stranger no more; I was theirs with every drop of my blood!" [16]. Queen Marie was also a great correspondent and writer of both, prose and poetry and in 1922 she wrote an "Ode to Roumania" in which she expresses her love of the country and its people: “...O Roumania, now are all thy children united, their chains broken, their captivity endedand the mountains barriers no longer exist....And now my people, it behoves us to reconstruct. The foundations are laid, the great work is begun. Build, build! All differences set aside; let us draw close together in this sacred unity which we have bought with our blood and which will constitute our strength. Stone by stone build up the future; with courage and with confidence advance; but so that the edifice which thou buildest may be indestructible, forget not the hearts, the countless hearts on which thou hast placed its stones." [17]. Queen Marie was beloved by the Romanian people and hailed as "Mother Queen" for her utmost dedication and service to the country and its people.

The area of Balcic located on the Silver Coast of the Black Sea, a touristy, sea resort and spa today, in present-day Bulgaria belonged to Romania between 1913-1940 and was the Summer residence of the Queen. Here, on this ancient Greek colony, founded in the $6^{\text {th }}$ century BCE by the Milesians and known as Dionysopolis in antiquity, Queen Marie completed her palace between 19261937, on a steep bluff overlooking the sea, inspired by the architectural style from the $16^{\text {th }}$ century of Curtea de Arges in Romania and surrounded by a number of residential villas, a wine cellar, a chapel and monastery, extensive botanical gardens and vistas. (Figure 8)

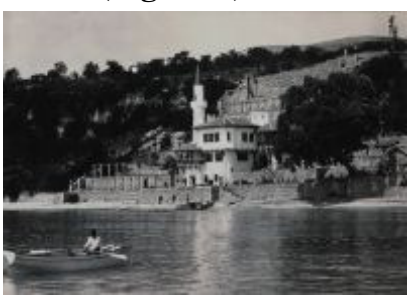

Figure 8. Queen Marie Palace Balcic

With the unfortunate partition of Romania in 1940, the palace was incorporated in Bulgaria and its numerous contents of paintings, ceramics, sculptures and the Queen's archive of correspondences and historical photographs were transferred to Constanta. The Queen was buried at Curtea de Arges, but she had requested that her heart would be buried in the Stella Maris Chapel in her palace at Balcic. With the loss of Balcic, her heart was moved a number of times to eventually be placed at her beloved Pelisor Castle in southern Transylvania where it still resides today [18].

\section{Topalu treasures and Balcic artistic visions}

On August 27, 1960 Dr. Gheorghe Vintila (1898-1978) one of the Chief and great surgeons of the 1930's to 1969 when he retired, donated 228 works of modern Romanian art, as a foundation for a museum, dedicated to commemorating and continuing the contribution of his parents to their community, Topalu, in Dobrogea. This museum was named "Dinu and Sevasta Vintila" in honor of his parents and is housed in his parent's home [19]. (Figure 9).



Figure 9. Topalu Museum interior view

The astonishing and remarkable collection includes a vast array of important Romanian artists like Grigorescu, Tonitza, Pallady, Petrascu, Ressu and many more - a surprising gem hidden in a small community off the beaten tourist track to the sea. Portraits, flowers, still lifes as well as seascapes and images of Balcic fill the rooms organized by period and grouped by artist, providing a venerable encyclopaedia of Romanian modern art. Upon its inauguration, the museum was hailed by Corneliu Baba 'a spiritual oasis in the desert' [20].

\section{Conclusion}

This paper provided a short overview of the inspiration the Dobrogea region and the palace of Balcic offered to various prominent Romanian painters of the modern period. Each artist approached the subject in a special, unique and individual style revealing fresh perspectives and affording the viewer a glimpse at the past with nostalgic vistas and sun drenched villages, capturing a time prior to the commercialized and touristy frenzy of the resorts that have overtaken the 
sea shore in more recent times. Their paintings attest to the creative spirit of Romania on a par to other, more prominent artistic movements of the $19^{\text {th }}$ and $20^{\text {th }}$ centuries in Europe, whose lessons and experiments were synthesized in new and distinct ways by the greatly admired Romanian artists.

\section{References}

[1]. Pool, P. Impressionism Thames \& Hudson 1991, p. 14-15.

[2]. Colection Genius Painters : "Life and work of Tonitza". \#11. The Truth. , Art Library. Truth Holding Press. 2009, ISBN 978-606-539-107-9, pp. 1-153.

[3]. Lassaigne Jacques, Stefan Luchian, Editions Meridiane, Bucharest, 1972, pp. 72-73, 110-113.

[4]. Jianu, Ionel, Comarnescu, Petru Stefan Luchian, Editura de Stat pentru Literatura si Arta, Bucuresti, 1956, pp. 133-147.

[5] Constantinescu Paula and Schobel Doina, Exhibition of Painting, G. Petrascu, 1872 - 1972, Museum of Art of the Romanian Socialist Republic Catalog, Bucharest, 1972, p. 66-70.

[6] Constantinescu Paula and Schobel Doina, Exhibiton of Painting, G. Petrascu, 1872 - 1972, Museum of Art of the Romanian Socialist Republic Catalog, Bucharest, 1972, p. 66-70.

[7]. Mesea Iulia, Gallery of Romanian Art, National Brukenthal Museum Guide, Sibiu, 2010, p. 98-102. [8]. Constantinescu Paula and Schobel Doina, Exhibition of Painting, G. Petrascu, 1872 - 1972, Museum of Art of the Romanian Socialist Republic Catalog, Bucharest,1972, p. 55-57, 62, 76, 78, 80.

[9] Constantinescu Paula and Schobel Doina, Exhibition of Painting, G. Petrascu, 1872 - 1972, Museum of Art of the Romanian Socialist Republic Catalog, Bucharest,1972, p. 55-57, 62, 76, 78, 80.

[10]. George Stefanescu Biography, retrieved from http://www.georgestefanescu.ro/biografie.php

[11]. George Stefanescu Biography, retrieved from http://www.georgestefanescu.ro/biografie.php [12]. George Stefanescu, retrieved from http://georgestefanescu.ro/category/articole/page/2/ [13]. Princess Marie of Edinburgh - Queen of Romania, retrieved from http://www.unofficialroyalty.com/princess-marieof-edinburgh-queen-of-romania/
[14]._Brenda Ralph Lewis, Queen Marie, retrieved from

http://www.tkinter.smig.net/queenmarie/mammareg ina/index.htm

[15]. Queen Marie, retrieved from

http://www.geh.org/link/SN/queen-marie.html

[16]. MY LIFE AS CROWN PRINCESS, Part 8, by Marie, Queen of Rumania, The Saturday Evening Post, 16 June 1934, retrieved from http://www.tkinter.smig.net/QueenMarie/SatEvePo st/1934-06-16/index.htm

[17]. ODE TO ROMANIA by H. M. Queen Marie of Roumania, from Roumania - The Royal Edition, Marie Jonnesco, Paris, 1922, retrieved from http://www.tkinter.smig.net/QueenMarie/OdeToRo umania/index.htm

[18]. Elizabeth Jane Timms, Burying a Queen's Heart - Queen Marie of Romania, retrieved from http://royalcentral.co.uk/blogs/history/burying-aqueens-heart-queen-marie-of-romania-52050

[19]._Doina Pauleanu, Muzeul de Arta Dinu si Sevasta Vintila Topalu Catalog, Editura Arcade, Bucuresti 2012, p.5

[20]. Doina Pauleanu, Muzeul de Arta Dinu si Sevasta Vintila Topalu Catalog, Editura Arcade, Bucuresti 2012, p.5 